\title{
STORAGE OF TREMA (Trema orientalis Linn. Blume) SEEDLINGS IN NURSERIES AND THEIR EFFECT ON GROWTH
}

\author{
(Penyimpanan Bibit Trema (Trema orientalis Linn. Blume) di Persemaian Serta Pengaruhnya \\ Terhadap Pertumbuhan)
}
Deddy Dwi Nur Cahyono, Dida Syamsuwida, Naning Yuniarti, Aam Aminah, Danu, Kresno Agus Hendarto, Dharmawati Djam'an, Y.M.M. Anita Nugraheni and/ dan Nurmawati Siregar
Forest Tree Seed Technology Research and Development Center (BP2TPTH)
Jl. Pakuan Ciheuleut PO Box 105; Telp. (0251) 8327768, Bogor, Jawa Barat, Indonesia
e-mail : deddydwi@yahoo.com

Paper submitted: : October $25^{\text {th }}, 2021$; Paper revised: November $19^{\text {th }}, 2021$; Paper accepted: December $16^{\text {th }}, 2021$

\section{ABSTRAK}

Trema (Trema orientalis Linn. Blume) adalah salah satu jenis tanaman hutan yang memiliki potensi untuk dimanfaatkan sebagai sumber bahan energi biomassa terbarukan. Keberhasilan pengembangan jenis ini sangat bergantung pada kualitas dan kuantitas bibitnya. Permasalahan yang sering terjadi adalah tertundanya bibit di persemaian karena menunggu kesiapan lahan dan musim penghujan tiba. Oleh karena itu, bibit perlu disimpan dengan menghambat pertumbuhannya selama penyimpanan. Tujuan penelitian adalah mengkaji respon pertumbuhan semai trema terhadap perlakuan bahan penghambat tumbuh dan naungan selama penyimpanan di persemaian dan penanaman di lapangan. Metoda pertumbuhan lambat digunakan dalam studi ini dengan memberi perlakuan bahan penghambat tumbuh (paklobutrazol 250 ppm, $\mathrm{NaCl}$ 0,5\%) dan mengatur kondisi naungan (90\% naungan, 50\% naungan dan tanpa naungan) serta disimpan selama 6 bulan. Setelah penyimpanan, tanaman hasil perlakuan diangkut dan ditanam di lapangan, selanjutnya diamati pertumbuhannya selama 17 bulan. Hasil penelitian menunjukkan bahwa pertumbuhan bibit trema dapat ditekan selama penyimpanan 6 bulan dengan mengaplikasikan paklobutrazol 250 ppm dibawah kondisi naungan $50 \%\left(T=32,2{ }^{\circ} \mathrm{C}\right.$; $R H=62 \%$, intensitas cahaya 27.300 lux $)$. Kondisi ini dapat menekan pertumbuhan diameter dan nisbah pucuk akar masing-masing sebesar 49\% dan 11\% serta dapat mempertahankan persen hidup bibit hingga 97,67\%. Pertumbuhan tinggi dan diameter terbaik di lapangan adalah kombinasi penggunaan $\mathrm{NaCl}$ dengan intensitas naungan 50\%. Efektivitas aplikasi bahan penghambat tumbuh pada tanaman saat penyimpanan di persemaian berbeda dengan yang digunakan untuk meningkatkan pertumbuhan tanaman di lapang.

Kata kunci : bibit, paklobutrazol, penghambat, penyimpanan, trema

\section{ABSTRACT}

Trema (Trema orientalis Linn. Blume) is one of forest tree species that has potency to be used as a renewable biomassa energy source. The successful of the development of this species is strongly depent on the quality and quantity of the seedlings. The problems often occur when the seedlings should be stacked up in a nursery due to the unreadiness of the planting sites and rainy season. Therefore, the seedlings should be stored and managed by suppressing their growth during storage. The aim of the study is to examine the growth responses of trema seedlings to the treatments of growth retardants and shade during storage in the nursery and replanting in the field. Slow growth method was used in this study by applying growth inhibitors ( $250 \mathrm{ppm}$ paclobutrazol, $0.5 \% \mathrm{NaCl}$ ) and regulating shade conditions $(90 \%$ shade, $50 \%$ shade and no shade) and stored for 6 months. After storing in the nursery, treated seedlings were replanted in the field and observing for their growth for 17 months. The results showed that the growth of the seedlings could be suppressed for 6 months by applying $250 \mathrm{ppm}$ paclobutrazol under $50 \%$ shade condition $\left(\mathrm{T}=32.2^{\circ} \mathrm{C}\right.$; $\mathrm{RH}=62 \%$, light intensity of 27,300 flux). This condition suppressed the growth of the diameter and root shoot ratio by an average of $49 \%$ and $11 \%$ respectively, and maintain the seedling survival up to $97.67 \%$. The best growth in height and diameter in the field was achieved by a combination of treatment using $\mathrm{NaCl}$ with a shade intensity of $50 \%$. It is concluded that the effectiveness of the application of inhibitors on trema seedlings when were stored in the nursery was different from that used to increase the growth of trema in the field.

\section{Keyword : inhibitor, seedling, paclobutrazol, storage, trema}




\section{INTRODUCTION}

Indonesia has potential renewable energy sources as alternative energy to replace fossil energy with its extensive forests, agriculture and biodiversity (Sidabutar, 2018). One of the alternative energy sources from forests is biomass. Trema (Trema orientalis) is one of the forest tree species that can potentially be developed as a biomass-based renewable energy source (Badan et al., 2020). In addition, this species can also be used for woodworking and pulp (Jahan, 2013), as medicine (Adinortey et al., 2013), and as a basic ingredient for skin beauty drugs (Beena et al., 2015). Considering those various potentials, the development of this species has to be considered that starting from the aspect of its cultivation. The correct handling of plant material is one factor to reach the success of the plantation so that the quality seedlings are always available in adequate quantities and at the right time.

Problems occur when the seedlings production already available and ready to be planted, must be delayed in planting due to the unreadiness of the rainy season. Thus, there is a certain period that the seedlings must be stored before planting. This condition may cause uncontrolled growth of seedlings during storage and interrupt the planting program. Seedling growth becomes diverse, and the height is not efficient for planting. Some efforts are needed to inhibit the growth during storage time, but the seedlings are still in vigorous conditions with optimum height and has uniformity when the seedlings were planted.

The efforts to inhibit seedling growth can be achieved by modifying environmental conditions such as temperature reduction (Karmila \& Andriani, 2019), light manipulation (Fukuda, 2019), and application of growth retardants such as paclobutrazol (Syamsuwida \& Aminah, 2011). Temperature modification can inhibit seedling growth, because in most tropical plant species, vegetative growth generally increases with increasing temperature (Hatfield \& Prueger, 2015). In terms of to energy sources, lighting is an important environmental factor for plant growth (Nelson \& Junge, 2015). Growth regulators can regulate plant growth patterns by inhibiting competition for nutrient utilization by vegetative and generative growth, resulting in a low distribution of assimilates to all plant parts (Serly et al., 2013). Paclobutrazol and $\mathrm{NaCl}$ as inhibitor agents have a similar mechanisms (Hawley, 1981) in which $\mathrm{Cl}$ ion analogically has the same mechanism as the $\mathrm{Cl}$ ion contained in paclobutrazol. In general, research in retarding growth plants during temporary storage in the nursery is aimed at those species with recalcitrant types. In this study, trema has 
intermediate character (Yuniarti et al., 2018), shade intolerant. In connection with these characteristics, a study was conducted to examine the response of trema seedling growth to the treatment of growth-inhibiting agents and shade during storage in the nursery and planting in the field.

\section{MATERIALS AND METHODS}

\section{A. Materials}

This study was carried out in Nagrak Research Station Nursery at Bogor, West Java for six months starting from March to September 2016. The planting location was carried out in Kesatuan Pemangkuan Hutan (KPH) Pekalongan Timur, Central Java in October 2016 and observed and measured in March 2018.

The materials were seeds of trema, laboratory equipment, field equipment, and chemicals. Laboratory equipment was used, especially glass tools, to make chemical solutions. Field equipment includes shading nets of $90 \%$ and $50 \%$ size, seedbeds, polybags, measuring instruments, standard planting media, thermometer, hygrometer, and lux meter. The chemicals are paclobutrazol $\left(\mathrm{C}_{15} \mathrm{H}_{2} \mathrm{OClN} \mathrm{Cl}_{3} \mathrm{O}\right)$ and $\mathrm{NaCl}$ as growth inhibitors.

\section{B. Procedure}

\section{Seed germination}

The seeds of about 1.000 were germinated in plastic seedbeds containing a mixture of sand-soil $(1: 1, \mathrm{v} / \mathrm{v})$, placed in a greenhouse and watered every day. About $70 \%$ of germinating seeds were grown and sprouts were allowed to grow until 5-6 weeks old.

\section{Treatment in the nursery}

Seedlings of 5-6 weeks old were transferred (weaned) into $10 \mathrm{~cm} \times 20 \mathrm{~cm}$ polybags, each containing mixed soil mediathusk charcoal $(2: 1, \mathrm{v} / \mathrm{v})$ and then placed in the seedbed. Based on their size performance, the seedlings were allowed to grow until they are strong, uniform, and ready for treatment. The seedlings that have become ready-to-plant seedlings are placed under the shading net with an intensity of $90 \%$ (temperature $(\mathrm{T})=32.8^{\circ} \mathrm{C}$; relative humidity $(\mathrm{RH})=64 \%$; light intensity $(\mathrm{LI})=5,350 \mathrm{lux})$, some are placed under $50 \%$ shading net $(\mathrm{T}=$ $32.2^{\circ} \mathrm{C} ; \mathrm{RH}=62 \%$, LI $\left.=27,300 \operatorname{lux}\right)$ and without shade $\left(\mathrm{T}=34^{\circ} \mathrm{C}, \mathrm{RH}=34 \%\right.$, LI $=$ 95,300 lux). Then the plants in each shade condition were sprayed with $10 \mathrm{ml} /$ plant of growth inhibitor paclobutrazol (250 ppm), $\mathrm{NaCl}(0.5 \%)$ and distilled water as a control (Syamsuwida \& Aminah, 2011). Seedlings were only sprayed once and in each treatment condition they were stored for six months and observed every month by measuring their growth. Watering was done every day.

\section{Planting in the field}

Seedlings that resulted from the treatment in the nursery (6 months old) were transported and planted in the field with a spacing of $3 \mathrm{~m} \mathrm{x}$ $3 \mathrm{~m}$. Planting was a randomized design with 
the number of repetitions of 3 blocks, each block consisting of 9 treatment combinations and each treatment combination containing 20 plants. The number of plants in 1 block was 180 , and the total number of observation units was 540 plants. After 17 months old, the plants were measured for their growth responses.

\section{Data Analysis}

The experiment consisted of 2 treatment factors, namely $\mathrm{A}=$ growth regulator $\left(\mathrm{A}_{1}=\right.$ distilled water, $A_{2}=$ paclobutrazol and $A_{3}=$ $\mathrm{NaCl})$ and $\mathrm{B}=$ storage conditions $\left(\mathrm{B}_{1}=\right.$ no shade, $\mathrm{B}_{2}=50 \%$ shade and $\mathrm{B}_{3}=90 \%$ shade). The experimental design in the nursery was a completely randomized design with a $3 \times 3$ factorial pattern with three replications to obtain nine treatment combinations and 27 experimental units. Each experimental unit consisted of 20 seedlings. The different treatments were tested by Duncan's Multiple Range Test. Storage was carried out for six months, the response of plant growth was measured every month. The growth responses measured were the survival rate, height growth and diameter growth increment to the all seedling sample. At the end of the observation, the biomass content and shoot root ratio were measured from two plant samples repeated three times.

The experimental design in the field was a block randomized design with three replications and nine treatment units. The growth responses observed were the survival rate, height growth, and diameter growth increment. The survival rate in each treatment group was transformed into arcsin before analysis. The significance of treatment difference was tested with the Tukey test.

\section{RESULT AND DISCUSSION}

\section{A. Result}

The growth regulators affected the growth of height and diameter of the seedlings. The growth of seedling diameter was affected significantly by either growth regulator or shading intensity factor and their interactions. The shoot and root ratio values were significantly influenced by the intensity of the shade and the interaction of the two factors. Total dry weight only affected by shade intensity. Meanwhile, the survival rate of seedlings was statistically equal (Table 1).

The results showed that paclobutrazol was more effective for inhibiting seedling growth during storage in the nursery than $\mathrm{NaCl}$. Meanwhile, total dry weight and shoot root ratio, although the values obtained from the paclobutrazol treatment showed low numbers, statistically not significantly different from the others.

The survival rate was statistically relatively equal, but the survival rate got highest value result when using paclobutrazol (Table 2). 
Table (Tabel) 1. Analysis summary of the influences of treatments on the growth parameters of trema seedlings (Rekapitulasi analisis varians pengaruh perlakuan terhadap parameter pertumbuhan bibit trema)

\begin{tabular}{|c|c|c|c|c|c|}
\hline $\begin{array}{l}\text { Treatments } \\
\text { (Perlakuan) }\end{array}$ & $\begin{array}{c}\text { Survival } \\
\text { rate } \\
\text { (Persentase } \\
\text { hidup) } \\
(\%)\end{array}$ & $\begin{array}{l}\text { Height growth } \\
\text { (Pertumbuhan } \\
\text { tinggi) } \\
(\mathrm{cm})\end{array}$ & $\begin{array}{l}\text { Diameter } \\
\text { growth } \\
\text { (Pertumbuhan } \\
\text { diameter }) \\
(\mathrm{mm})\end{array}$ & $\begin{array}{l}\text { Total dry } \\
\text { weight } \\
\text { (Berat } \\
\text { kering } \\
\text { total) } \\
\text { (g) }\end{array}$ & $\begin{array}{l}\text { Top root } \\
\text { ratio } \\
\text { (Nisbah } \\
\text { pucuk } \\
\text { akar) } \\
\text { (g) }\end{array}$ \\
\hline $\begin{array}{l}\text { Growth regulators } \\
\text { (Bahan pengatur tumbuh) }\end{array}$ & $0.638 \mathrm{~ns}$ & $0.087^{*}$ & $0.002 * *$ & $0.903 \mathrm{~ns}$ & $0.57 \mathrm{~ns}$ \\
\hline $\begin{array}{l}\text { Shading intensity } \\
\text { (Intensitas naungan) }\end{array}$ & $0.115 \mathrm{~ns}$ & $0.616 \mathrm{~ns}$ & $0.049 * *$ & $0.030 * *$ & $0.00 * *$ \\
\hline Interaction (Interaksi) & $0.864 \mathrm{~ns}$ & $0.281 \mathrm{~ns}$ & $0.016 * *$ & $0.550 \mathrm{~ns}$ & $0.023 * *$ \\
\hline
\end{tabular}

Table (Tabel) 2. Significant different test of the effect of growth regulators, shading intensities and their interaction on the growth parameters of trema (Rekapitulasi nilai rata-rata hasil uji beda nyata pengaruh bahan pengatur tumbuh, intensitas naungan dan interaksi keduanya terhadap parameter pertumbuhan bibit trema)

\begin{tabular}{|c|c|c|c|c|c|}
\hline $\begin{array}{l}\text { Treatments } \\
\text { (Perlakuan) }\end{array}$ & $\begin{array}{c}\text { Survival rate } \\
\text { (Persentase hidup) } \\
(\%)\end{array}$ & $\begin{array}{l}\text { Height growth } \\
\text { (Pertumbuhan } \\
\text { tinggi) } \\
(\mathrm{cm})\end{array}$ & $\begin{array}{l}\text { Diameter growth } \\
\text { (Pertumbuhan } \\
\text { diameter }) \\
(\mathrm{mm})\end{array}$ & $\begin{array}{l}\text { Total dry } \\
\text { weight } \\
\text { (Berat kering } \\
\text { total) } \\
(\mathrm{g})\end{array}$ & $\begin{array}{l}\text { Top root ratio } \\
\text { (Nisbah pucuk } \\
\text { akar) } \\
\text { (g) }\end{array}$ \\
\hline \multicolumn{6}{|c|}{ Growth regulators (Bahan pengatur tumbuh) } \\
\hline Aquadest $\left(\mathrm{A}_{1}\right)$ & $88.33 \mathrm{a}$ & $6.32 \mathrm{ab}$ & $1.15 \mathrm{a}$ & $0.44 \mathrm{a}$ & $0.27 \mathrm{a}$ \\
\hline $\begin{array}{l}\text { Paclobutrazol }\left(\mathrm{A}_{2}\right) \\
\mathrm{NaCl} \text { solution }\left(\mathrm{A}_{3}\right)\end{array}$ & $\begin{array}{l}91.67 \mathrm{a} \\
86.11 \mathrm{a}\end{array}$ & $\begin{array}{l}5.59 \mathrm{~b} \\
7.86 \mathrm{a}\end{array}$ & $\begin{array}{l}0.63 \mathrm{~b} \\
1.04 \mathrm{a}\end{array}$ & $\begin{array}{l}0.37 \mathrm{a} \\
0.40 \mathrm{a}\end{array}$ & $\begin{array}{l}0.28 \mathrm{a} \\
0.32 \mathrm{a}\end{array}$ \\
\hline \multicolumn{6}{|c|}{ Shading intencity (Intensitas naungan) } \\
\hline $\begin{array}{l}\text { No shading }\left(\mathrm{B}_{1}\right) \\
50 \%\left(\mathrm{~B}_{2}\right) \\
90 \%\left(\mathrm{~B}_{3}\right)\end{array}$ & $\begin{array}{l}95.56 \mathrm{a} \\
82.78 \mathrm{a} \\
87.78 \mathrm{a}\end{array}$ & $\begin{array}{l}6.06 \mathrm{a} \\
7.03 \mathrm{a} \\
6.69 \mathrm{a} \\
\end{array}$ & $\begin{array}{r}0.88 \mathrm{ab} \\
1.13 \mathrm{a} \\
0.81 \mathrm{~b} \\
\end{array}$ & $\begin{array}{r}0.64 \mathrm{a} \\
0.40 \mathrm{ab} \\
0.18 \mathrm{~b} \\
\end{array}$ & $\begin{array}{l}0.30 \mathrm{a} \\
0.16 \mathrm{~b} \\
0.48 \mathrm{c}\end{array}$ \\
\hline \multicolumn{6}{|l|}{ Interaction (Interaksi) } \\
\hline $\begin{array}{l}A_{1} B_{1} \\
A_{1} B_{2}\end{array}$ & $\begin{array}{l}96.67 \mathrm{a} \\
78.33 \mathrm{a}\end{array}$ & $\begin{array}{l}6.98 \mathrm{a} \\
6.30 \mathrm{a}\end{array}$ & $\begin{array}{l}1.34 \mathrm{ab} \\
1.05 \mathrm{ab}\end{array}$ & $\begin{array}{l}1.09 \mathrm{a} \\
0.89 \mathrm{a}\end{array}$ & $\begin{array}{r}0.28 \mathrm{bc} \\
0.26 \mathrm{~b}\end{array}$ \\
\hline $\begin{array}{l}\mathrm{A}_{1} \mathrm{~B}_{3} \\
\mathrm{~A}_{2} \mathrm{~B}_{1}\end{array}$ & $\begin{array}{l}90.00 \mathrm{a} \\
98.33 \mathrm{a}\end{array}$ & $\begin{array}{l}5.69 \mathrm{a} \\
5.68 \mathrm{a}\end{array}$ & $\begin{array}{r}1.06 \mathrm{ab} \\
0.64 \mathrm{~b}\end{array}$ & $\begin{array}{l}2.83 \mathrm{a} \\
1.97 \mathrm{a}\end{array}$ & $\begin{array}{l}0.41 \mathrm{a} \\
0.22 \mathrm{~b}\end{array}$ \\
\hline $\mathrm{A}_{2} \mathrm{~B}_{2}$ & $90.00 \mathrm{a}$ & $5.92 \mathrm{a}$ & $0.75 \mathrm{~b}$ & $0.61 \mathrm{a}$ & $0.11 \mathrm{~b}$ \\
\hline $\mathrm{A}_{2} \mathrm{~B}_{3}$ & $86.67 \mathrm{a}$ & $5.18 \mathrm{a}$ & $0.49 \mathrm{~b}$ & $0.77 \mathrm{a}$ & $0.49 \mathrm{a}$ \\
\hline $\mathrm{A}_{3} \mathrm{~B}_{1}$ & $91.67 \mathrm{a}$ & $5.53 \mathrm{a}$ & $0.67 \mathrm{~b}$ & $1.52 \mathrm{a}$ & $0.40 \mathrm{ab}$ \\
\hline $\mathrm{A}_{3} \mathrm{~B}_{2}$ & $80.00 \mathrm{a}$ & $8.86 \mathrm{a}$ & $1.59 \mathrm{a}$ & $1.38 \mathrm{a}$ & $0.11 \mathrm{~b}$ \\
\hline $\mathrm{A}_{3} \mathrm{~B}_{3}$ & $86.67 \mathrm{a}$ & $9.20 \mathrm{a}$ & $0.87 \mathrm{ab}$ & $0.98 \mathrm{a}$ & $0.35 \mathrm{ab}$ \\
\hline
\end{tabular}


The effect of various shade intensities was seen on the growth of height, total dry weight and shoot root ratio (Table 2). Shade with an intensity of $90 \%$ caused the lowest growth in seedling height and total dry weight. However, the lowest shoot root ratio was achieved by seedlings shaded with a $50 \%$ shading net. The intensity of shade or no shade did not cause a difference in height growth parameters and survival rate.

The interaction between the treatment of growth retardants and shade intensity influenced the growth parameters of the diameter and shoot root ratio, while the others did not (Table 2).

The interaction with the lowest diameter increases value $(0.49 \mathrm{~mm})$ was achieved using paclobutrazol treatment and $90 \%$ shade intensity (A2B3). Meanwhile, a low shoot root ratio was achieved by combining paclobutrazol treatment with a shade intensity of $50 \%(\mathrm{~A} 2 \mathrm{~B} 2)$ and a combination of $\mathrm{NaCl}$ with a shade intensity of $50 \%$ (A3B2). At the field level, the treatment results had a significant effect on diameter growth (Table $3)$.

Table (Tabel) 3. F-test recapitulation of effect seed storage on survival, height growth, and diameter growth of 17 months old trema (Rekapitulasi F-hitung pengaruh perlakuan penyimpanan bibit terhadap persen hidup, pertumbuhan tinggi dan pertumbuhan diameter trema umur 2 tahun)

\begin{tabular}{|c|c|}
\hline $\begin{array}{c}\text { Source of variance } \\
\text { (Sumber keragaman) }\end{array}$ & $\begin{array}{l}\mathrm{F} \text { calculate } \\
\left(F_{\text {hitung }}\right)\end{array}$ \\
\hline \multicolumn{2}{|l|}{ Survival rate (Persentase hidup) } \\
\hline Treatments (Perlakuan) & $0.99^{\text {ns }}$ \\
\hline Block $($ Blok) & $0.68^{\mathrm{ns}}$ \\
\hline \multicolumn{2}{|l|}{ Height growth (Pertumbuhan tinggi) } \\
\hline Treatments (Perlakuan) & $2.26^{\mathrm{ns}}$ \\
\hline Block (Blok) & $1.63^{\mathrm{ns}}$ \\
\hline \multicolumn{2}{|l|}{ Diameter growth (Pertumbuhan diameter) } \\
\hline Treatments (Perlakuan) & $3.42^{* *}$ \\
\hline Block (Blok) & $1.43^{\mathrm{ns}}$ \\
\hline $\begin{aligned} \text { Remarks (Keterangan) }: & * * \text { highly significantly } \\
& \text { nyata pada selang kep } \\
& \text { (tidak berbeda nyata) }\end{aligned}$ & $\begin{array}{l}\text { e level (berbec } \\
\text { t significantly }\end{array}$ \\
\hline
\end{tabular}

Based on the results (Table 4), the best diameter growth was achieved by the seedlings with a combination of $\mathrm{NaCl}$ treatment and $50 \%$ shade intensity $\left(\mathrm{A}_{3} \mathrm{~B}_{2}\right)$. Statistically in diameter growth, the $\mathrm{A}_{3} \mathrm{~B}_{2}$ treatment was only significantly different from $\mathrm{A}_{1} \mathrm{~B}_{1}$ and $\mathrm{A}_{3} \mathrm{~B}_{1}$, while the others were not. 
Table (Tabel) 4. Survival rate, height, and diameter growth of 17 months old trema (Persen hidup, pertumbuhan tinggi dan pertumbuhan diameter trema umur 2 tahun)

\begin{tabular}{crrr}
\hline $\begin{array}{c}\text { Treatments } \\
\text { (Perlakuan })\end{array}$ & $\begin{array}{c}\text { Survival rate } \\
\text { (Persentase hidup })(\%)\end{array}$ & $\begin{array}{c}\text { Height growth } \\
\text { (Pertumbuhan tinggi) }(\mathrm{cm})\end{array}$ & $\begin{array}{c}\text { Diameter growth (Pertumbuhan } \\
\text { diameter) }(\mathrm{mm})\end{array}$ \\
\hline $\mathrm{A}_{1} \mathrm{~B}_{1}$ & $45.0 \mathrm{a}$ & $63.9 \mathrm{a}$ & $7.4 \mathrm{~b}$ \\
$\mathrm{~A}_{1} \mathrm{~B}_{2}$ & $40 \mathrm{a}$ & $80.4 \mathrm{a}$ & $12.4 \mathrm{ab}$ \\
$\mathrm{A}_{1} \mathrm{~B}_{3}$ & $70 \mathrm{a}$ & $75.8 \mathrm{a}$ & $10.2 \mathrm{ab}$ \\
$\mathrm{A}_{2} \mathrm{~B}_{1}$ & $48.3 \mathrm{a}$ & $77.3 \mathrm{a}$ & $10.7 \mathrm{ab}$ \\
$\mathrm{A}_{2} \mathrm{~B}_{2}$ & $50 \mathrm{a}$ & $66.3 \mathrm{a}$ & $10.3 \mathrm{ab}$ \\
$\mathrm{A}_{2} \mathrm{~B}_{3}$ & $55 \mathrm{a}$ & $75.1 \mathrm{a}$ & $9.1 \mathrm{ab}$ \\
$\mathrm{A}_{3} \mathrm{~B}_{1}$ & $36.6 \mathrm{a}$ & $66.3 \mathrm{a}$ & $7.7 \mathrm{~b}$ \\
$\mathrm{~A}_{3} \mathrm{~B}_{2}$ & $75 \mathrm{a}$ & $83.8 \mathrm{a}$ & $14.9 \mathrm{a}$ \\
$\mathrm{A}_{3} \mathrm{~B}_{3}$ & $53.3 \mathrm{a}$ & $93.4 \mathrm{a}$ & $11.7 \mathrm{ab}$ \\
\hline
\end{tabular}

Remarks (Keterangan) : The numbers follow by the same letter are not significantly different at $1 \%$ (Angka-angka yang diikuti oleh huruf yang sama tidak berbeda nyata pada taraf $1 \%$ ); treatment information see Table 2.

\section{B. Discussion}

At the nursery level, paclobutrazol was more effective than $\mathrm{NaCl}$ in inhibiting the height growth of trema seedlings. Plant height growth is the activity of cell division in the apical meristem, beginning with the addition of shoots that are getting longer and then continued with their development into leaves and stems. The stages in shoot growth are cell division, extension, and maturation (Herdiana et al., 2008). Paclobutrazol inhibits the extension of plant segments, so this will affect seedling height growth (Lienargo et al., 2014; Irawan \& Iwanuddin, 2015). The hormone gibberellin in plants plays a role in the process of cell elongation and determines plant height. Paclobutrazol works as an inhibitor for gibberellin synthesis by inhibiting the oxidation of kaurene to kaurenoic acid. The growth inhibition process caused by the application of paclobutrazol arises because the chemical components in paclobutrazol block three stages for gibberellin production in the terpenoid pathway by inhibiting enzymes catalyze the metabolic reaction process (Hedden \& Graebe, 1985). Plants given paclobutrazol have lower gibberellin content than those without paclobutrazol so that the growth of plant meristems and cell elongation will be inhibited. Physically, there is compression of the internodes, which results in compact and short plants.

Apart from being effective on trema, paclobutrazol is also able to inhibit seedling height growth of several forest plants such as S. assamica (Irawan \& Iwanuddin, 2015; Irawan \& Darwo, 2017) and Magnolia tsiampaca (Irawan et al., 2018). In ornamental plants such as red shoots (Roseli et al., 2012), hibiscus flowers (Nazarudin, 2012), orchids (Hidayah et al., 2019), and sunflowers (Marshel et al., 2015). In agriculture, paclobutrazol is also used to inhibit plant height growth. This inhibition is usually aimed at preventing overcrowding of plants and increasing productivity such as rice (Barus et 
al., 2018), potatoes (Hamdani et al., 2018), and cloves (Runtunuwu et al., 2011). In medicinal plant such as rodent tuber plant (Sianipar et al., 2019), Cynodon dactylon (L.) Pers. (Arghavani et al., 2016), Etlingera elatior (Jack) R.M. Smith (Muangkaewngam $\&$ Te-Chato, 2018).

Trema seedling's diameter growth was smaller after being treated with paclobutrazol than $\mathrm{NaCl}$. The inhibition of growth that occurs in stem diameter where the process of stem cell division is inhibited causes the growth rate of stem increment to decrease. Gao et al. (1988) stated that the morphological and anatomical characteristics of the impact of paclobutrazol growth-regulating agents include shortening the shoots of the seedlings. Noor (2009) also revealed that giving paclobutrazol to Shorea spp tillers affected the apical point of growth and thickness or thinness and cross-sectional area of plant leaves. The direct effect on plants is that the apical point of growth seems to stop and affects the function of the stomata on the leaves; this can affect the growth of plant diameter.

After treatment, the survival rate of trema seedlings did not show a significant difference with a relatively high value, namely an average of $78.33-97.67 \%$. Survival rate $>90 \%$ was achieved by trema seedlings after spraying paclobutrazol, whereas with other treatments $<$
$90 \%$. In the condition without shade, the administration of paclobutrazol resulted in a relatively high seedling survival rate $(98.33 \%)$. According to Berova et al. (2002) paclobutrazol not only inhibits vegetative growth but can protect plants from extreme environmental conditions such as temperatures that are too high or low. The protection given by paclobutrazol to plants is due to the increased free radical removal system.

The total dry weight (biomass) of trema seedlings was more influenced by the shade treatment where the emphasis occurred after being given $90 \%$ and $50 \%$ shade. Seedlings under $90 \%$ shade result in low total dry weight values. Trema plants are shade intolerant. Thus, when trema seedlings are placed under dense shade, growth is stunted and low biomass. Growth inhibition occurs at stem diameter, which causes the biomass value to decrease.

Another parameter that was influenced by the paclobutrazol was the shoot root ratio. The cell division activity for root growth of trema seedlings appears to be inhibited by the inhibitor of $250 \mathrm{ppm}$ paclobutrazol, which causes the root ratio to decrease compared to the upper plants. A decrease in the shoot ratio value also occurred in the interaction between paclobutrazol or $\mathrm{NaCl}$ with $50 \%$ shade. The reduction in light entering during storage accompanied by inhibition of growth with an 
inhibiting agent causes root growth to be stunted, resulting in a reduced shoot root ratio. Fukuda (2019) states that one of the environmental factors that affect plant growth is light intensity. The light intensity that enters the $50 \%$ shade is still sufficient for plants to carry out photosynthesis so that metabolism is still running well, although not optimal, but still vigor is indicated by the relatively high survival rate during storage.

$\mathrm{NaCl}$ is not included in the growth inhibitor group, however, this chemical in the form of salt can be an ingredient to inhibit plant growth. According to (Mindari, 2009) the higher salt content concentration in the soil, the more stunted plant growth. Many plant species experience decreased growth when exposed to salinity stress (Krismiratsih et al., 2020). Asih et al. (2015) stated that the response of plants to increasing $\mathrm{NaCl}$ concentrations varies depending on the type of plant. High $\mathrm{NaCl}$ concentrations can increase or decrease the growth rate in plants. The element content of sodium $\left(\mathrm{Na}^{+}\right)$has the same function as the element potassium $\left(\mathrm{K}^{+}\right)$, so that it can replace the function of potassium $\left(\mathrm{K}^{+}\right)$in maintaining water content in leaves. Yufdy (2008) states that the effect of $\mathrm{Na}^{+}$will be very large if the supply of $\mathrm{K}^{+}$for plants is insufficient. Furthermore, this element can reduce the effect caused by the lack of $\mathrm{K}^{+}$but cannot completely replace the $\mathrm{K}^{+}$function. In the context of photosynthesis, $\mathrm{Na}^{+}$is an essential element for plants. The importance of $\mathrm{Na}^{+}$for plants is in terms of osmoregulation and turgor maintenance and to control stomatal activity. The addition of $\mathrm{Na}^{+}$increased plant $\mathrm{K}$ uptake but had no effect on the dry biomass yield of maize (Nursyamsi et al., 2008). Meanwhile, chlorine $(\mathrm{Cl})$ is an essential nutrient that plants always need, even though in a small amount, which functions to stimulate the activity of several enzymes to affect water absorption in plant tissues (Sudarmi, 2013).

The results of storage treatment in the nursery mentioned above only affected the diameter growth of two years old plants in the field, while the other parameters did not. The best diameter growth was achieved by combining $\mathrm{NaCl}$ treatment with a shade intensity of $50 \%$. The growth of the plants in the field resulting from paclobutrazol treatment was not as fast as the $\mathrm{NaCl}$ treatment. This is thought caused by $\mathrm{NaCl}$ application during storage which did not inhibit the synthesis of gibberellin in the seedlings compared to the use of paclobutrazol. Thus, when stress is released, the effect of gibberellin in plants for growth is faster than paclobutrazol during storage. Young leaves are one of the main sites for gibberellin synthesis and stimulate stem elongation because young leaves send hormone synthesis to the stem (Gupta \& Chakrabarty, 2013; Hedden, 2020). 


\section{CONCLUSION}

The growth of trema seedlings during six months of storage in the nursery could be inhibited by application of $250 \mathrm{ppm}$ paclobutrazol under $50 \%$ shade $\left(\mathrm{T}=32.2^{\circ} \mathrm{C}\right.$; $\mathrm{RH}=62 \%, \mathrm{LI}=27,300$ lux), but the best growth in the field is those seedlings resulting from the treatment of storage using $\mathrm{NaCl}$ and $50 \%$ shade. The effectiveness of the application of inhibitors on trema seedlings when was stored in the nursery was different from that used to increase the growth of trema in the field.

\section{ACKNOWLEDGEMENT}

The authors would like to thank to the Head of Forest Tree Seed Technology Research Centre Bogor for funding this research. We would also like to thank the field foreman and his team in the area KPH Pekalongan Timur, so that research activities can be carried out properly.

\section{REFERENCES}

Adinortey, M. B., Galyuon, I. K., \& Asamoah, N. O. (2013). Trema orientalis Linn. Blume: A potential for prospecting for drugs for various uses. Pharmacognosy Reviews, 7(13), 67-72. https://doi.org/10.4103/0973-7847.112852

Arghavani, M., Kheiry, A., Savadkoohi, S., \& Taheri, S. (2016). Growth and phytochemical content of Cynodon dactylon (L.) Pers. as affected by Trinexapac-ethyl and paclobutrazol. Journal of Medicinal Plants and By Products, 5(1), 7-13. https://doi.org/10.22092/JMPB.2016.108918

Asih, E. D., Mukarlina, \& Lovadi, I. (2015). Toleransi Tanaman Sawi Hijau (Brassica juncea L.) Terhadap Cekaman Salinitas Garam NaCl. Jurnal Protobiont, 4(1), 203-
208.

https://jurnal.untan.ac.id/index.php/jprb/article /view/9764

Badan, P., Thepchatri, T., Tanavat, E., Haruthaithanasan, M., \& Haruthaithanasan, K. (2020). Fuel Properties of Some Native Tree Species for Biomass Energy in Thailand. Thai Journal of Agricultural Science, 53(1), 53-57. https://li01.tcithaijo.org/index.php/TJAS/article/download/2 $45610 / 167895$

Barus, H., Ratna, \& Meiriani. (2018). Pengaruh waktu aplikasi paclobutrazol terhadap pertumbuhan dan produksi tiga varietas padi sawah (Oriza sativa L.). Jurnal Agroekoteknologi, 6(1), 7-13. https://talenta.usu.ac.id/joa/article/view/2517

Beena, C., Kanakamany, M. T., \& Sindhu, P. V. (2015). Trema orientalis L. - The waste land tree as a source of hydroquinone. International Journal of Research and Scientific Innovation, II(I), 147-148. https://www.academia.edu/10211868/Trema orientalis_L_The_Waste_Land_Tree_as_a_So urce_of_Hydroquinone

Berova, M., Zlatev, Z., \& Stoeva, N. (2002). Effect of paclobutrazol on wheat seedlings under low temperature stress. Bulg. J. Plant Physiol., 28(1-2), 75-84. http://www.bio21.bas.bg/ipp/gapbfiles/v28/02_1-2_75-84.pdf

Fukuda, N. (2019). Plant growth and physiological responses to light conditions. In M. Anpo, H. Fukuda, \& T. Wada (Eds.), Plant Factory Using Artificial Light: Adapting to Environmental Disruption and Clues to Agricultural Innovation (pp. 71-77). Elsevier Inc.https://doi.org/https://doi.org/10.1016/B97 8-0-12-813973-8.00008-7

Gao, J., Hofstra, G., \& Fletcher, R. A. (1988). Anatomical changes induced by triazoles in wheat seedlings. Canadian Journal of Botany, $66(1)$ $1178-1185$. https://doi.org/https://doi.org/10.1139/b88168

Gupta, R., \& Chakrabarty, S. K. (2013). Gibberellic acid in plant: Still a mystery unresolved. Plant Signaling and Behavior, $8(9)$, 
https://doi.org/https://doi.org/10.4161/psb.255 04

Hawley, G.G. (1981). Condeses Chemical Dictionary $10^{\text {th }}$ ed. Nostrand Reinhold Co. New York. P 40

Hamdani, J. S., Nuraini, A., \& Mubarok, S. (2018). The use of paclobutrazol and shading net on growth and yield of potato 'medians' tuber of G2 in medium land of Indonesia. Journal of Agronomy, 17(1), 62-67. https://doi.org/10.3923/ja.2018.62.67

Hatfield, J. L., \& Prueger, J. H. (2015). Temperature extremes: Effect on plant growth and development. Weather and Climate Extremes, $10, \quad 4-10$. https://doi.org/https://doi.org/10.1016/j.wace. 2015.08.001

Hedden, P. (2020). The current status of research on gibberellin biosynthesis. Plant and Cell Physiology, 61(11), 1832-1849. https://doi.org/https://doi.org/10.1093/pcp/pca a092

Hedden, P., \& Graebe, J. E. (1985). Inhibition of gibberellin biosynthesis by paclobutrazol in cell-free homogenates of Cucurbita maxima endosperm and Malus pumila embryos. Journal of Plant Growth Regulation, 4, 111122.https://doi.org/https://doi.org/10.1007/BF 02266949

Herdiana, N., Lukman, A. H., \& Mulyadi, K. (2008). Pengaruh dosis dan frekuensi aplikasi pemupukan NPK terhadap pertumbuhan bibit Shorea ovalis Korth. (Blume.) asal anakan alam di persemaian. Jurnal Penelitian Hutan Dan Konservasi Alam, V(3), 289-296. https://doi.org/https://doi.org/10.20886/jphka. 2008.5.3.289-296

Hidayah, S. N., Karno, \& Kusmiyati, F. (2019). Respon tanaman anggrek (Dendrobium sp) terhadap pemberian paklobutrazol dan jenis naungan yang berbeda. Jurnal Agro Complex, $3(1)$, 24-31. https://doi.org/https://doi.org/10.14710/joac.3. 1.24-31

Irawan, A., \& Darwo. (2017). Respon pertumbuhan semai Shorea assamica Dyer terhadap tingkat naungan dan perlakuan bahan penghambat tumbuh. Jurnal Penelitian Kehutanan Wallacea, 6(1), 21-29. https://doi.org/http://dx.doi.org/10.18330/jwal lacea.2017.vol6iss 1pp21-29

Irawan, A., Halawane, J. E., \& Hidayah, H. N. (2018). Teknik penyimpanan semai cempaka wasian (Magnolia tsiampaca (Miq.)Dandy) menggunakan zat pengatur tumbuh dan perlakuan media tanam. Jurnal Penelitian Hutan Tanaman, 15(2), 67-145. https://doi.org/https://doi.org/10.20886/jpht.20 18.15.2.87-96

Irawan, A., \& Iwanuddin. (2015). Efektifitas penggunaan bahan penghambat tumbuh pada bibit Shorea assamica Dyer di persemaian. Jurnal Wasian, 2(1), 41-46. https://doi.org/https://doi.org/10.20886/jwas.v $2 \mathrm{i} 1.869$

Jahan, M. S. (2013). Prospect of Trema orientalis as a pulping raw material in Bangladesh. Science Vision, 19(1-2), 13-20. http://www.sciencevision.org.pk/?PageID=Vo 119_ContentsPage

Karmila, R., \& Andriani, V. (2019). Pengaruh temperatur terhadap kecepatan pertumbuhan kacang tolo (Vigna sp.). STIGMA: Jurnal Matematika Dan Ilmu Pengetahuan Alam Unipa, 12(1), 49-53. https://doi.org/https://doi.org/10.36456/stigma .vol12.no01.a1861

Krismiratsih, F., Winarso, S., \& Slamerto. (2020). Cekaman garam $\mathrm{NaCl}$ dan teknik aplikasi azolla pada tanaman padi. Jurnal Ilmu Pertanian Indonesia, 25(3), 349-355. https://doi.org/https://doi.org/10.18343/ipi.25. 3.349

Lienargo, B. R., Runtuwunu, S. D., Rogi, J. E. X., $\&$ Tumewu, P. (2014). Pengaruh waktu penyemprotan dan konsentrasi paclobutrazol (PBZ) terhadap pertumbuhan dan produksi tanaman jagung (Zea mays L.) varietas manado kuning. Jurnal Cocos, 4(1), 1-9. https://ejournal.unsrat.ac.id/index.php/cocos/a rticle/view/3485

Marshel, E., Bangun, M. K., \& Putri, L. A. P. (2015). Pengaruh waktu dan konsentrasi paclobutrazol terhadap pertumbuhan bunga matahari (Hellianthus Annuus L.). Jurnal Agroekoteknologi, 3(3), 929-937. https://jurnal.usu.ac.id/index.php/agroekotekn ologi/article/view/10916 
Mindari, W. (2009). Cekaman garam dan dampaknya pada kesuburan tanah dan pertumbuhan tanaman (M. Prof. Dr. Ir. Syekhfani (ed.)). UPN Veteran Jawa Timur. https://www.researchgate.net/profile/WantiMindari/publication/320009095

Muangkaewngam, A., \& Te-Chato, S. (2018). Morphological and physiological responses of torch ginger [Etlingera elatior (Jack) R.M. Smith] to paclobutrazol application. International Journal of Agricultural Technology, 14(4), 559-570. http://www.ijataatsea.com/pdf/v14_n4_2018_

July/10_IJAT_14(4)_2018_Muangkaewngam, A..pdf

Nazarudin, A. (2012). Plant growth retardants effect on growth and flowering of potted Hibiscus rosa-sinensis L. Journal of Tropical Plant Physiology, 4, 29-40. https://jtpp.org.my/volume/4/vol4_article3.pdf

Nelson, N., \& Junge, W. (2015). Structure and energy transfer in photosystems of oxygenic photosynthesis. Annual Review of Biochemistry, $\quad 84, \quad 26.1-26.25$. https://doi.org/https://doi.org/10.1146/annurev -biochem-092914-041942

Noor, M. (2009). Pengaruh pemberian paklobutrazol terhadap pertumbuhan semai Shorea spp. di persemaian. Jurnal Penelitian Dipterokarpa, 3(1), 21-32. https://doi.org/https://doi.org/10.20886/jped.2 009.3.1.21-32

Nursyamsi, D., Idris, K., Sabiham, S., Rachim, D. A., \& Sofyan, A. (2008). Pengaruh asam oksalat, $\mathrm{Na}+, \mathrm{NH} 4+$, dan $\mathrm{Fe} 3+$ terhadap ketersediaan $\mathrm{K}$ tanah, serapan $\mathrm{N}$, P dan $\mathrm{K}$ tanaman, serta produksi jagung pada tanahtanah yang didominasi smektit. Jurnal Tanah dan Iklim, 28, 69-82. http://ejurnal.litbang.pertanian.go.id/index.ph $\mathrm{p} / \mathrm{jti} /$ article/view/229

Roseli, A. N. M., Ying, T. F., \& Ramlan, M. F. (2012). Morphological and physiological response of Syzygium myrtifolium (Roxb.) Walp. to paclobutrazol. Sains Malaysiana, 41(10), 1187-1192. https://www.ukm.my/jsm/pdf_files/SM-PDF41-10-2012/02 Ahmad Nazarudin.pdf

Runtunuwu, S. D., Mamarimbing, R., Tumewu, P.,
\& Sondakh, T. (2011). Konsentrasi paclobutrazol dan pertumbuhan tinggi bibit cengkeh (Syzygium aromaticum (L.) Merryl \& Perry). Eugenia, 17(2), 135-142. https://doi.org/https://doi.org/10.35791/eug.17 .2 .2011 .3535

Serly, Sengin, E. L., \& Riadi, M. (2013). Respon pertumbuhan dan produksi ubi jalar (Ipomoea batatas L.) yang diaplikasikan paclobutrazol dan growmore 6-30-30. Thesis, 45, 1-14. http://pasca.unhas.ac.id/jurnal/files/e0adb4140 6a361fdd5f213bd4c145e27.pdf

Sianipar, N. F., Naftalia, \& Purnamaningsih, R. (2019). In vitro preservation of rodent tuber (Typhonium flagelliforme lodd.) pekalongan accession with paclobutrazol. Jurnal Teknologi, 81(3), 4955.https://doi.org/https://doi.org/10.11113/jt.v 81.12818

Sidabutar, V. T. P. (2018). Kajian peningkatan potensi ekspor pelet kayu indonesia sebagai sumber energi biomassa yang terbarukan. Jurnal Ilmu Kehutanan, 12(1), 99-116. https://doi.org/https://doi.org/10.22146/jik.341 25

Sudarmi. (2013). Pentingnya unsur hara mikro bagi pertumbuhan tanaman. Widyatama, 22(2). https://docplayer.info/36704679-Pentingnyaunsur-hara-mikro-bagi-pertumbuhan tanaman.html

Syamsuwida, D., \& Aminah, A. (2011). Teknik penyimpanan semai kayu bawang (Dysoxylum moliscimum) melalui pemberian zat penghambat tumbuh dan pengaturan naungan. Jurnal Penelitian Hutan Tanaman, 8(3), 147153.https://doi.org/https://doi.org/10.20886/jp ht.2011.8.3.147-153

Yufdy, M. P. (2008). Pemanfaatan hara dari air laut untuk memenuhi kebutuhan tanaman. Jurnal Sumberdaya Lahan, 2(2), 75-82. http://ejurnal.litbang.pertanian.go.id/index.ph $\mathrm{p} / \mathrm{js} 1 /$ article/view/201

Yuniarti, N., Syamsuwida, D., \& Kurniaty, R. (2018). Perubahan viabilitas, vigor, dan biokimia benih trema (Trema orientalis Linn. Blume) selama penyimpanan. Jurnal Penelitian Kehutanan Wallacea, 7(1), 83-92. https://doi.org/http://dx.doi.org/10.18330/jwal lacea.2018.vol7iss1pp83-92 
STORAGE OF TREMA (Trema orientalis Linn. Blume) SEEDLINGS IN NURSERIES AND THEIR EFFECT ON GROWTH

Deddy Dwi Nur Cahyono, Dida Syamsuwida, Naning Yuniarti, Aam Aminah, Danu, Kresno Agus Hendarto, Dharmawati Djam'an, Y.M.M. Anita Nugraheni and Nurmawati Siregar 